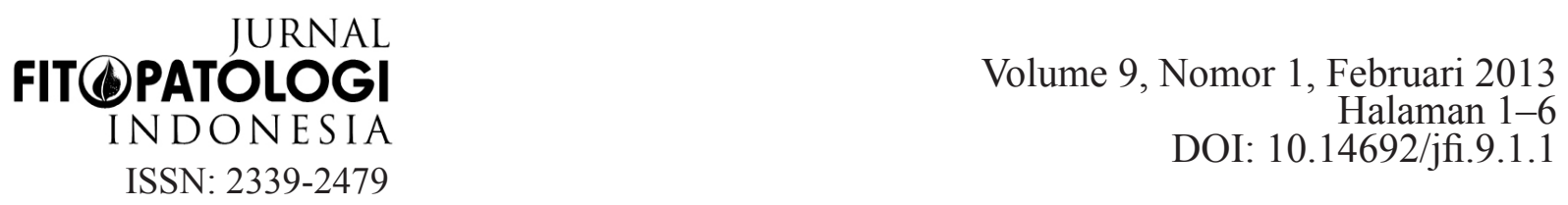

\title{
Identifikasi Spesies Meloidogyne pada Wortel berdasarkan Sikuen Nukleotida
}

\author{
Species Identification of Meloidogyne on Carrot \\ based on Their Nucleotide Sequences
}

\author{
Halimah, Supramana*, Gede Suastika \\ Institut Pertanian Bogor, Bogor 16680
}

\begin{abstract}
ABSTRAK
Nematoda puru akar (NPA), Meloidogyne spp., telah dilaporkan menjadi penyebab umbi bercabang pada wortel di beberapa sentra produksi sayuran di Jawa Tengah dan Jawa Timur. Pada penelitian ini dilakukan identifikasi secara molekuler spesies NPA yang menginfeksi wortel di Agropolitan Cianjur, Jawa Barat dan penelusuran tingkat kekerabatannya dengan spesies NPA dari negara lain. DNA diekstraksi dari nematoda betina dan diamplifikasi melalui polymerase chain reaction (PCR) menggunakan primer spesifik spesies (Rjav/Fjav untuk M. javanica, Rar/Far untuk M. arenaria dan Rinc/Finc untuk M. incognita) dan primer multipleks (M. hapla, M. chitwoodi, dan M. fallax). Sikuensing nukleotida dilakukan terhadap DNA hasil PCR tanpa melalui proses kloning. Berdasarkan hasil identifikasi ada dua spesies NPA berasosiasi dengan penyakit umbi bercabang, yaitu M. javanica dan M. hapla. Analisis pohon filogenesis memperlihatkan bahwa $M$. javanica asal Cianjur berkerabat sangat dekat dengan $M$. javanica asal Cina dengan tingkat homologi mencapai 91.9\%. Nematoda M. hapla asal Cianjur mempunyai sikuen nukleotida dengan tingkat homologi antara 99.4\% sampai $100 \%$ dengan isolat-isolat dari Swiss, Amerika, Inggris, dan Cina.
\end{abstract}

Kata kunci: filogenesis, Meloidogyne hapla, M. javanica, nematoda puru akar

\begin{abstract}
Root-knot nematodes (RKN), Meloidogyne spp., were reported as the cause of carrot branched tuber on several vegetable production areas in Central and East Java. Species identification by molecular approach was conducted using infected carrot tubers from Agropolitan Cianjur, West Java. DNA was extracted from female nematodes and amplified using PCR with species specific primers (Fjav/Rjav for $M$. javanica, Far/Rar for M. arenaria, and Finc/Rinc for M. incognita) and multiplex primer ( $M$. hapla, M. chitwoodi, and M. fallax). PCR product were sequenced without cloning. Based on nucleotide sequences, two species RKN were found associated with branched tuber disease of carrot in Agropolitan Cianjur, i.e M. javanica and M. hapla. Phylogenetic analysis showed that M. javanica from Cianjur was closely related to RKN from China with the homology level of $91.9 \%$, whereas nucleotide sequence of M. hapla from Cianjur had high homology level (99.4\% to 100\%) with isolates from Swiss, USA, UK, and China.
\end{abstract}

Key words: Meloidogyne hapla, M. javanica, phylogenetic, root-knot nematode

*Alamat penulis korespondensi: Departemen Proteksi Tanaman, Fakultas Pertanian, Institut Pertanian Bogor, Kampus Darmaga, Jalan Kamper, Bogor 16680

Tel: 0251-8629364, Faks: 0251-8629362, Surel: supramana@ipb.ac.id 


\section{PENDAHULUAN}

Wortel merupakan jenis sayuran umbi yang banyak dikonsumsi saat ini. Produksi wortel Indonesia tahun 2009 hingga 2011 meningkat dari 358014 ton menjadi 526917 ton (BPS 2012). Selama periode tersebut penurunan produktivitas wortel sebesar 2.20 ton/ha terjadi di Jawa Barat, 2.48 ton/ha di Sumatera Utara, dan 6.39 ton/ha di Sulawesi Utara.

Meloidogyne spp. yang sering disebut nematoda puru akar (NPA) merupakan penyebab penyakit umbi bercabang pada wortel. Kehilangan hasil akibat infeksi NPA dilaporkan sebesar 15\% hingga 95\% (Kurniawan 2010). NPA juga merupakan patogen penting pada tanaman wortel di Amerika Serikat (Gugino et al. 2006), Brazil (Charchar et al. 2009), Turki (Devran dan Sogut 2009), dan Eropa (Wesemael et al. 2011).

Saat ini identifikasi nematoda secara cepat dan akurat telah dikembangkan menggunakan pendekatan biologi molekul di antaranya dengan teknik polymerase chain reaction (PCR). Metode ini menggunakan struktur asam nukleat, misalnya internal transcribed spacer (ITS) rDNA sebagai dasar untuk menentukan karakter dan mengidentifikasi patogen tanaman.

Penelitian ini bertujuan mengidentifikasi secara molekuler spesies NPA yang berasosiasi dengan penyakit umbi bercabang pada wortel di daerah sentra produksi wortel di Jawa Barat serta mengetahui tingkat kekerabatannya dengan spesies Meloidogyne dari negara lain.

\section{BAHAN DAN METODE}

Sampel berupa tanaman wortel bergejala umbi bercabang dikoleksi dari Agropolitan Cianjur. Daerah ini mempunyai ketinggian 1300-1600 m dpl dan merupakan salah satu sentra produksi wortel di Jawa Barat. Identifikasi Meloidogyne spp. dilakukan menggunakan teknik PCR dan sikuen nukleotida. Proses identifikasi dilakukan di Laboratorium Nematoda dan Laboratorium Virologi, Fakultas Pertanian, Institut Pertanian Bogor.

\section{Ekstraksi DNA}

Puru akar direndam selama 24 jam, dibedah menggunakan jarum bedah, dan diekstraksi menggunakan metode Hikmia et al. (2012) yang telah dimodifikasi. Dua puluh ekor nematoda betina dimasukkan ke dalam tabung eppendorf. Sampel tersebut ditambah bufer ekstrak $(200 \mathrm{mM}$ Tris $\mathrm{HCl} \mathrm{pH}$ 8.0, $25 \mathrm{mM}$ EDTA $\mathrm{pH}$ 8.0, dan 0.5\% SDS) sebanyak $150 \mu \mathrm{Ldan}$ digerus hingga halus dengan cornical grinder steril. Selanjutnya, $150 \mu \mathrm{L}$ kloroform:isoamilakohol (24:1) ditambahkan dan disentrifugasi pada kecepatan $11000 \mathrm{rpm}$ selama 10 menit.

Sebanyak $100 \mu \mathrm{L}$ supernatan dimasukkan ke dalam tabung eppendorf baru, ditambah $50 \mu \mathrm{L}$ larutan sodium asetat $\left(\mathrm{CH}_{3} \mathrm{COONa}\right) 3 \mathrm{M}$ dan $\mathrm{pH}$ 5.2, dibolak-balik dan disimpan pada suhu $-20{ }^{\circ} \mathrm{C}$ selama 10 menit. Setelah itu suspensi disentrifugasi pada kecepatan $12000 \mathrm{rpm}$ selama 20 menit. Supernatan diambil sebanyak $100 \mu \mathrm{L}$ dan dipindahkan ke dalam tabung eppendorf baru. Isopropanol ditambah 1 volume ke dalam tabung, dibolakbalik, disimpan pada suhu ruang selama 30 menit, dan selanjutnya disentrifugasi pada kecepatan 12000 rpm selama 20 menit. Supernatan dibuang dan ditambah etanol $80 \%$ sebanyak 1 volume, disentrifugasi pada kecepatan 12000 rpm selama 15 menit dan supernatan dibuang. Endapan DNA dikeringkan, ditambah $30-100 \mu \mathrm{L}$ bufer TE $\mathrm{pH} 8$ sesuai ketebalan pelet DNA, dan disimpan pada suhu $-20{ }^{\circ} \mathrm{C}$ hingga digunakan.

\section{Amplifikasi DNA dengan PCR}

Setiap reaksi PCR yang menggunakan primer spesifik spesies terdiri atas $12.5 \mu \mathrm{L} \mathrm{2x}$ Go Taq ${ }^{\circledR}$ Green Master mix (Promega), $1 \mu \mathrm{L}$ primer Forward $10 \mu \mathrm{M}, 1 \mu \mathrm{L}$ primer Reverse $10 \mu \mathrm{M}, 1 \mu \mathrm{L}$ templat DNA, dan $9.5 \mu \mathrm{L}$ air bebas nuklease sehingga volume menjadi $25 \mu \mathrm{L}$.

Reaksi PCR yang menggunakan primer multipleks spesies terdiri atas $12.5 \mu \mathrm{L} \mathrm{2x}$ Go $\mathrm{Taq}^{\circledR}$ Green Master mix (Promega), $1 \mu \mathrm{L}$ primer forward JMV1 $10 \mu \mathrm{M}, 1 \mu \mathrm{L}$ primer reverse JMV2 $10 \mu \mathrm{M}, 1 \mu \mathrm{L}$ primer reverse JMV hapla $10 \mu \mathrm{M}, 1 \mu \mathrm{L}$ templat DNA, dan $8.5 \mu \mathrm{L}$ air bebas nuklease sehingga volume menjadi $25 \mu \mathrm{L}$. 
Amplifikasi dengan primer JMV1/JMV hapla akan menghasilkan pita berukuran $440 \mathrm{pb}$ untuk M. hapla, $540 \mathrm{pb}$ untuk M. chiwoodi, dan 670 pb untuk M. fallax (Tabel 1) (Adam et al. 2007).

Proses denaturasi untuk setiap DNA spesies Meloidogyne terjadi pada suhu $94{ }^{\circ} \mathrm{C}$ selama 4 menit. Proses annealing untuk setiap DNA spesies yang diuji memerlukan waktu dan suhu yang berbeda. Proses annealing spesies M. javanica pada suhu $55^{\circ} \mathrm{C}$ selama 45 detik, $M$. incognita pada suhu $57^{\circ} \mathrm{C}$ selama 45 detik, M. arenaria pada suhu $55^{\circ} \mathrm{C}$ selama 45 detik, dan $M$. hapla pada suhu $50^{\circ} \mathrm{C}$ selama 30 detik (Adam et al. 2007). Proses elongation terjadi pada suhu $72{ }^{\circ} \mathrm{C}$ selama 1 menit, final elongation pada suhu $72{ }^{\circ} \mathrm{C}$ selama 7 menit, dan final hold $4{ }^{\circ} \mathrm{C}$.

DNA nematoda hasil amplifikasi diseparasi pada gel agarosa $1 \%$ yang dilarutkan dalam bufer TBE. Elektroforesis dilakukan pada tegangan 50 Volt selama 60 menit, kemudian dilanjutkan 100 Volt selama 5 menit. Hasil elektroforesis divisualisasi menggunakan sinar UV, dan gambar pita-pita DNA difoto dengan kamera digital (Hikmia et al. 2012).

\section{Perunutan DNA}

Perunutan DNA dilakukan menggunakan pasangan primer spesifik $M$. javanica dan primer multipleks $M$. hapla di PT Macrogen Incorporation Seoul, Korea Selatan (Tabel 1). Hasil sikuensing dianalisis menggunakan program basic local alignment search tool (BLAST) dengan program optimasi untuk mendapatkan urutan basa DNA yang terdapat dalam situs National Center for Biotechnology Information (NCBI). Identitas didapatkan dengan menggunakan software ClustalW (Bioedit), sedangkan pohon filogenesis menggunakan software MEGA dan neighbour joining (NJ) menggunakan 1000 bootstrap.

\section{HASIL}

PCR menggunakan primer spesifik $M$. javanica terhadap sampel NPA dari Jawa Barat berhasil mengamplifikasi pita DNA berukuran 720 pb (Gambar 1). Hasil ini mengindikasi bahwa NPA yang telah diteliti merupakan salah satu isolat $M$. javanica. Hasil sikuen nukleotida NPA asal Cianjur mempunyai tingkat kemiripan yang sangat tinggi (homologi 91.9\%) dengan spesies $M$. javanica asal Cina, sedangkan dengan spesies lain (M. hapla, M. arenaria, dan M. incognita) tingkat kemiripan hanya sebesar $35.7 \%$ hingga 40.1\% (Tabel 2).

Berdasarkan analisis filogenesis $M$. javanica asal Cianjur, Jawa Barat menjadi satu kelompok dengan isolat $M$. javanica asal Cina dan terpisah dari spesies-spesies $M$. javanica dari negara lain. Hal ini menunjukkan bahwa spesies $M$. javanica Cianjur memiliki tingkat kekerabatan lebih dekat dengan $M$. javanica asal Cina dibandingkan dengan spesies yang sama asal negara lain (Gambar 2).

Amplifikasi yang dilakukan menggunakan primer multipleks, yaitu JMV1, JMV2, JMV hapla hanya berhasil mendapatkan pita

Tabel 1 Primer yang digunakan untuk identifikasi spesies Meloidogyne asal Jawa Barat

\begin{tabular}{llcc}
\hline Kode & \multicolumn{1}{c}{ Sekuen (dari ujung $-5^{\prime}$ ke -3') } & $\begin{array}{c}\text { Ukuran pita hasil } \\
\text { PCR }(\mathrm{pb})\end{array}$ & $\begin{array}{c}\text { Spesies } \\
\text { NPA }\end{array}$ \\
\hline Fjav & GGTGCGCGATTGAACTGAGC & 720 & M. javanica \\
Rjav & CAGGCCCTTCAGTGGAACTATAC & & \\
Finc & CTGGCGATAGAGGTAAATGAC & 999 & M. incognita \\
Rinc & TCGGCGATAGACACTACAAACT & & \\
Far & TCGGCGATAGAGGTAAATGAC & 420 & M. arenaria \\
Rar & CTGGCGATAGACACTACAAAACT & 540 & M. chitwood \\
JMV1 & GGATGGCGTGCTTTCAAC & 670 & M. fallax \\
JMV2 & TTCCCCCTTACGATGTTTACCC & 440 & M. hapla \\
JMV hapla & AAAAATCCCCTCGAAAAATCCACC & & \\
\hline
\end{tabular}


DNA berukuran $440 \mathrm{pb}$ untuk M. hapla dan tidak berhasil mengamplifikasi pita DNA berukuran $540 \mathrm{pb}$ untuk $M$. chitwoodi maupun $670 \mathrm{pb}$ untuk M. fallax (Gambar 1). Hasil ini menunjukkan bahwa sampel DNA yang dideteksi hanya M. javanica dan M. hapla.

Keberadaan $M$. hapla ini juga diperkuat oleh analisis homologi sikuen nukleotida. Melalui analisis tersebut terlihat bahwa NPA

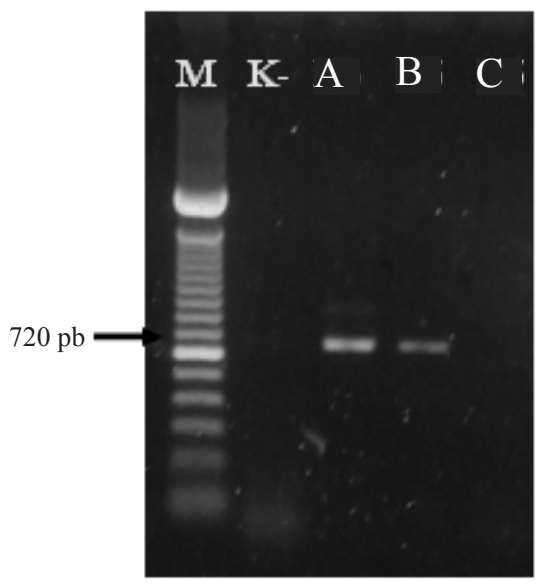

M. javanica asal Cianjur memiliki tingkat kemiripan yang sangat tinggi $(100 \%)$ dengan spesies M. hapla asal Magelang, Jawa Tengah begitu juga dengan spesies $M$. hapla asal negara lain dengan tingkat kemiripan antara $99.4 \%$ hingga 100\% (Tabel 3).

Berdasarkan hasil analisis filogenesis sikuen nukleotida disimpulkan bahwa isolat M. hapla asal Cianjur, dan Magelang menjadi

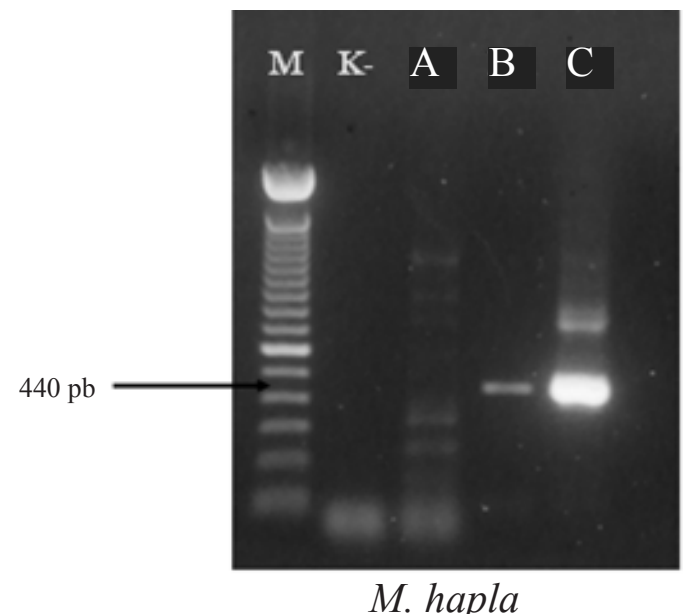

M. hapla

Gambar 1 Hasil amplifikasi DNA Meloidogyne isolat Cianjur, Jawa Barat dari beberapa tempat dengan ketinggian yang berbeda pada $1 \%$ gel agarosa elektroforesis. M, Penanda DNA $1 \mathrm{~kb}$; K (-), Tanaman sehat; A, 1300 m dpl; B, 1500 m dpl; C, 1600 m dpl.

Tabel 2 Homologi sikuen nukleotida DNA Meloidogyne javanica Cianjur, Jawa Barat dengan sikuen DNA yang ada pada GenBank

\begin{tabular}{lc}
\hline Isolat & Homologi dengan M. javanica Cianjur (\%) \\
\hline M. javanica Cina & 91.9 \\
M. arenaria & 35.7 \\
M. incognita & 35.7 \\
M. hapla & 40.1 \\
\hline
\end{tabular}

Matriks identitas sikuen diperoleh dengan menggunakan software Bioedit 7.1.3

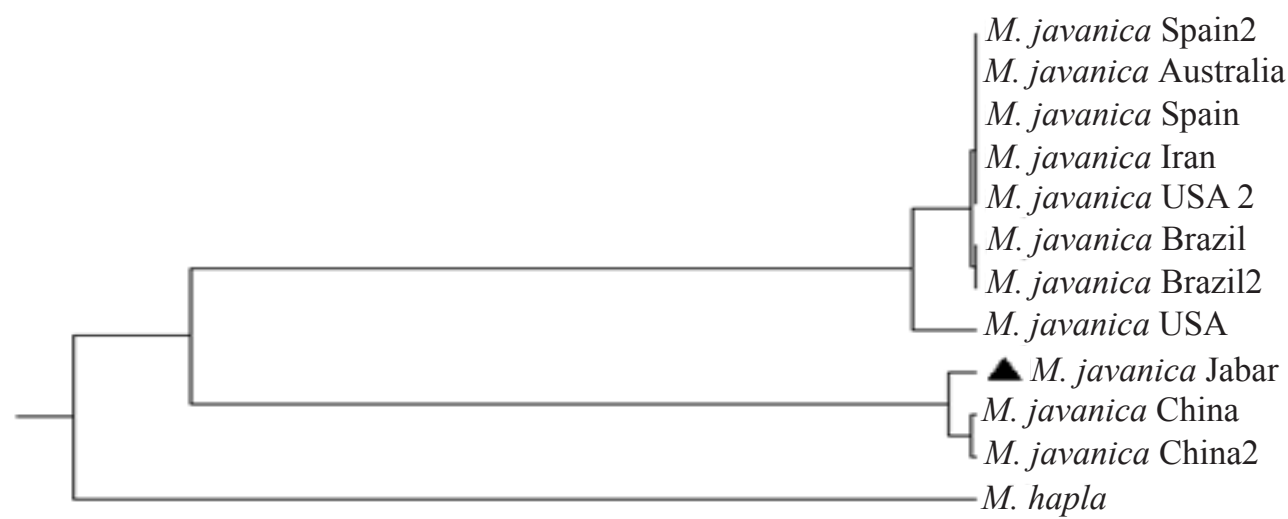

Gambar 2 Pohon filogenesis spesies Meloidogyne javanica yang menginfeksi pertanaman wortel di Cianjur, Jawa Barat. 
satu kelompok tersendiri dengan isolat $M$. hapla asal Inggris, Amerika, Cina, Australia dan Hawai serta terpisah dari kelompok $M$. hapla asal Swiss (Gambar 3).

\section{PEMBAHASAN}

M. javanica merupakan spesies nematoda dengan sebaran yang sangat luas di daerah tropik sampai subtropik, memiliki kisaran inang yang beragam dan menyebabkan kerusakan yang tinggi pada berbagai jenis tanaman sayuran. Secara ekologi $M$. javanica dapat hidup pada suhu $10-35{ }^{\circ} \mathrm{C}$ (Stephan 1982).

M. hapla adalah salah satu spesies Meloidogyne yang dapat bertahan pada suhu rendah $\left(4^{\circ} \mathrm{C}\right.$ hingga $\left.20^{\circ} \mathrm{C}\right)$ dan menginfeksi tanaman sayuran (Das et al. 2011). M. hapla termasuk organisme OPTK A2 yang sudah ada di Indonesia dengan daerah sebar terbatas, yaitu di Jawa. Dilaporkan sebelumnya, bahwa M. hapla telah menginfeksi pertanaman wortel di Kota Batu, Jawa Timur (Hikmia et al. 2012), dan Dataran Tinggi Dieng, Jawa Tengah (Taher et al. 2012). Namun menurut www.plantwise.org, wilayah Indonesia yang sudah terinfeksi $M$. hapla adalah Makassar, Sulawesi Selatan dan Yogyakarta, Jawa Tengah.

Berdasarkan hasil penelitian ini, $M$. hapla juga ditemukan di daerah Agropolitan Cianjur, Jawa Barat. Isolat M. hapla dari Jawa Barat memiliki homologi yang tinggi dengan isolat-isolat dari negara lain (Cina, Inggris, Hawai, Australia, dan Amerika). Oleh karena itu, diduga M. hapla telah lama masuk ke Indonesia dan mengalami perubahan genetik untuk menyesuaikan diri terhadap lingkungan di Indonesia. Data BPS (2005) menyebutkan bahwa Cina, Inggris, Amerika, dan Swiss merupakan beberapa negara pemasok wortel

Tabel 3 Homologi sikuen nukleotida DNA Meloidogyne hapla Cianjur, Jawa Barat dengan sekuen DNA yang ada pada GenBank.

\begin{tabular}{lc}
\hline Isolat & Homologi M. javanica Cianjur (\%) \\
\hline M. hapla Magelang & 100.0 \\
M. hapla Cina & 100.0 \\
M. hapla Inggris & 100.0 \\
M. hapla Amerika & 99.7 \\
M. hapla Swiss & 99.4 \\
M. javanica & 42.3 \\
M. arenaria & 52.7 \\
M. incognita & 53.0 \\
\hline
\end{tabular}

Matriks identitas sekuen diperoleh dengan menggunakan software Bioedit 7.1.3

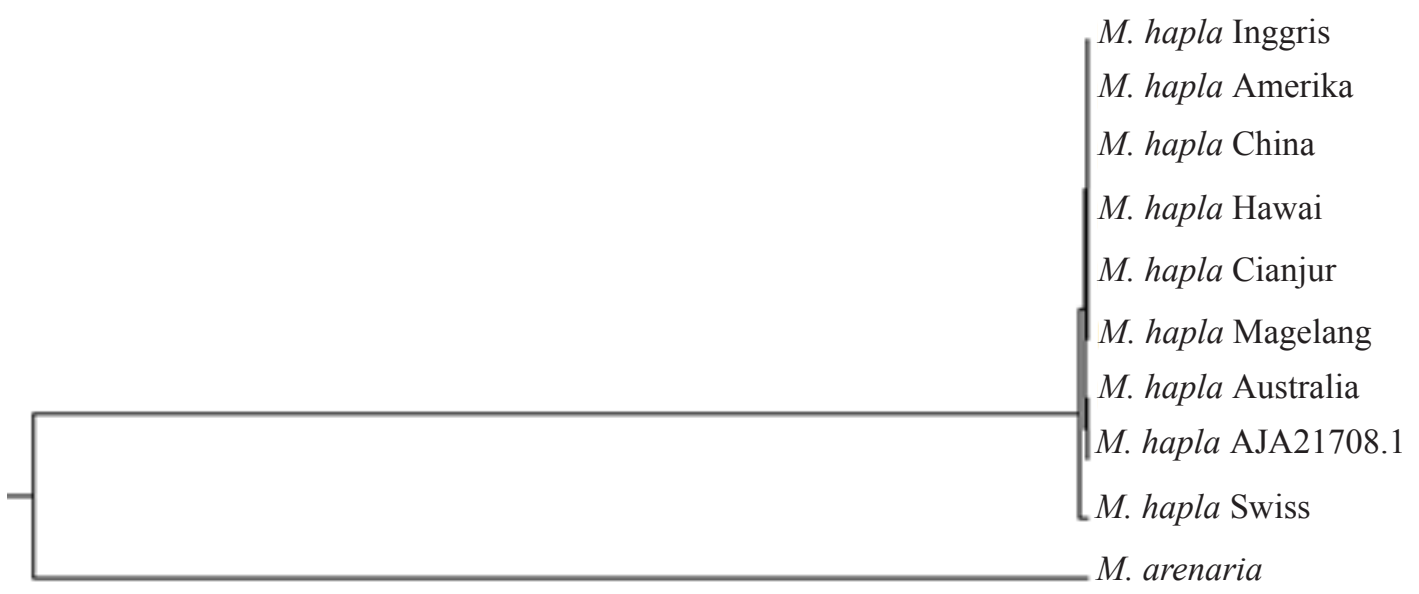

Gambar 3 Pohon filogenesis spesies Meloidogyne hapla yang menginfeksi pertanaman wortel di Cianjur, Jawa Barat. 
bagi Indonesia. Umbi wortel dari negara lain tersebut berpotensi sebagai agens pembawa patogen.

\section{DAFTAR PUSTAKA}

Adam MAM, Phillips MS, Blok CV. 2007. Molecular diagnostic key for identification of single juveniles of seven common and economically important species of rootknot nematode Meloidogyne spp. Plant Pathol. 56(1):190-197. DOI: http://dx.doi. org/10.1111/j.1365-3059.2006.01455.x.

[BPS] Badan Pusat Statistik. 2005. Buletin Statistik Perdagangan Luar Negeri, Impor. Jakarta (ID): BPS Indonesia.

[BPS] Badan Pusat Statistik. 2012. Luas panen, produksi dan produktivitas wortel, 2009-2011. www.bps.go.id [diakses 8 Oktober 2012].

Charchar JM, Eisenback JD, Vieira JV, Boiteux MENF, Boiteux LS. 2009. Meloidogyne polycephannulata n. sp. (Nematoda: Meloidogynidae), a root-knot nematode parasitizing carrot in Brazil. J Nematol. 41(3):174-186.

Das S, Wesemael WML, Perry RN. 2011. Effect of temperature and time on the survival and energy reserves of juveniles of Meloidogyne spp. Agric Sci Res J. 1(5):102-112.

Devran Z, Sogut MA. 2009. Distribution and identification of root-knot nematodes from Turkey. J Nematol. 41(2):128-133.
Gugino BK, Abawi GS, Ludwig JW. 2006. Damage and management of Meloidogyne hapla using oxamyl on carrot in New York. J Nematol. 38:483-490.

Hikmia Z, Supramana, Suastika G. 2012. Identifikasi spesies Meloidogyne spp. penyebab umbi bercabang pada tanaman wortel di Jawa Timur. J Fitopatol Indones. 8(3):73-78. DOI: http://dx.doi. org/10.14692/jfi.8.3.73.

Kurniawan W. 2010. Identifikasi penyakit umbi bercabang pada wortel, Daucus carota (L.) di Indonesia [tesis]. Bogor (ID): Institut Pertanian Bogor.

Plantwise. Meloidogyne hapla. http://www. plantwise.org [diakses 11 Mei 2012].

Stephan ZA. 1982. The influence of temperature and storage time on eggs of four species of Meloidogyne. Nematol Medit. 10:167-173.

Taher M, Supramana, Suastika G. 2012. Identifikasi Meloidogyne penyebab penyakit umbi bercabang pada wortel di Dataran Tinggi Dieng. J Fitopatol Indones. 8(1):16-21. DOI: http://dx.doi. org/10.14692/jfi.8.1.16.

Wesemael WML, Viaene N, Moens M. 2011. Root knot nematodes (Meloidogyne spp.) in Europe. JNematol. 13(1):3-16. DOI: http:// dx.doi.org/10.1163/138855410X526831. 